研

究

Al-Fe-Cr-Ti-Mm (Mm: ミッシュメタル) およびAl-V-Fe-Mm 合金P/M 材の組織と機械的性質

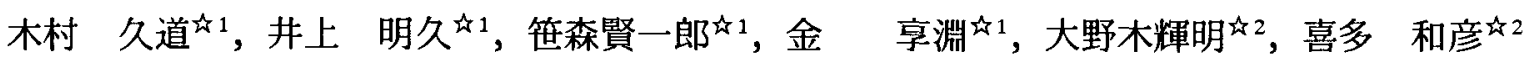

的1 東北大学金属材料研究所, 干 850-8577 仙台市青葉区片平 2-1-1.

${ }^{2} 2$ YKK (侏)金属材料研究所, 干 981-3341 宮城県黒川郡富谷町成田 9-5-1.

\title{
Microstructure and Mechanical Properties of P/M Al-Fe-Cr-Ti-Mm (Mm: Misch Metal) and $\mathrm{Al}-\mathrm{V}-\mathrm{Fe}-\mathrm{Mm}$ Alloys
}

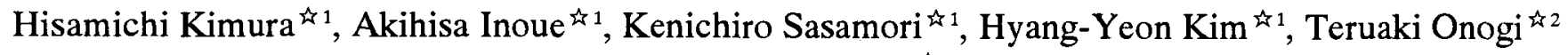 \\ and Kazuhiko Kita ${ }^{\text {出 }}$ \\ मे Institute for Materials Research, Tohoku University, Sendai 980-8577. \\ it 2 Sendai Institute of Materials Science \& Technology, YKK, 9-5-1 Narita, Tomiya-cho, Kurokawa-gun, Miyagi 981-3341.
}

Received September 4, 1997

\begin{abstract}
SYNOPSIS
$\mathrm{Al}-\mathrm{Fe}-\mathrm{Cr}-\mathrm{Ti}$ and $\mathrm{Al}-\mathrm{V}-\mathrm{Fe}$ alloys prepared by the powder metallurgy $(\mathrm{P} / \mathrm{M})$ process have high strength exceeding $600 \mathrm{MPa}$, high-elevated temperature strength exceeding $300 \mathrm{MPa}$ after holding for 100 hours at $573 \mathrm{~K}$ and more excellent wear resistance than commercial A390 aluminum alloy. In this work mechanical properties of the P/M $\mathrm{Al}_{93} \mathrm{Fe}_{3} \mathrm{Cr}_{2} \mathrm{Ti}_{2}$ and $\mathrm{Al}_{94} \mathrm{~V}_{4} \mathrm{Fe}_{2}$ alloys were found to be improved by the addition of misch metal (Mm). P/M $\mathrm{Al}_{9_{2}} \mathrm{Fe}_{3} \mathrm{Cr}_{2} \mathrm{Ti}_{2} \mathrm{Mm}_{1}$ alloys containing quasicrystalline phase were prepared by extrusion of argon gas atomized powders

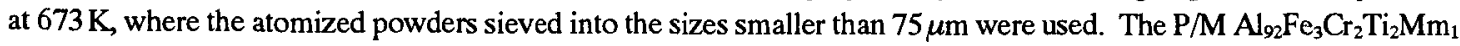
alloy has a mixed structure consisting of $\mathrm{Al}$, quasicrystal and compounds phases and exhibits good mechanical properties as follows: ultimate tensile strength $\left(\sigma_{U T S}\right)$ of $680 \pm 13 \mathrm{MPa}, 0.2 \%$ proof strength $\left(\sigma_{0.2}\right)$ of $670 \pm 10 \mathrm{MPa}$, plastic elongation $\left(\varepsilon_{\mathrm{P}}\right)$ of $0.3 \pm 0.1 \%$, Young's modulus (E) of $91 \pm 3 \mathrm{GPa}$ and Vickers hardness (Hv) of $230 \pm 3$, respectively, at room temperature, and $\sigma_{\mathrm{Urs}}$ of $347 \pm 5 \mathrm{MPa}, \sigma_{0.2}$ of $315 \pm 3 \mathrm{MPa}$ and $\varepsilon_{\mathrm{P}}$ of $1.8 \pm 0.3 \%$, respectively, after holding for 100 hours at $573 \mathrm{~K}$.
\end{abstract}

KEYWORDS

aluminum-based alloy, quasicrystalline phase, powder metallurgy, mechanical property

\section{1 緒 言}

著者らは，液体急冷 $(\mathrm{RQ})$ 法および粉末治金 $(\mathrm{P} / \mathrm{M})$ 法によっ て準結晶合金の特徴である高硬度 ${ }^{1,2)}$, 優れた熱的安定性 ${ }^{1,3)}$ 利用したナノ準結晶粒子分散 $\mathrm{Al}$ 合金 ${ }^{4-の}$ の開発を行ってきて いる. 近年, P/M 法で作製した準結晶を含む $\mathrm{Al}-\mathrm{Fe}-\mathrm{Cr}-\mathrm{Ti}$ 系 ${ }^{7-10}$ および $\mathrm{Al}-\mathrm{V}-\mathrm{Fe}$ 系 ${ }^{11-14)}$ 合金 $\mathrm{P} / \mathrm{M}$ 材は，引張強度が超々ジュラ ルミンを上回ること 7,810)，573Kで100h保持後の耐熱強度が耐 熱 $\mathrm{Al}$ 合金の目標值である $300 \mathrm{MPa}^{15)}$ を上回ること罗12.14)，耐摩 耗性が商用の耐摩耗アルミニウム合金(A390-T6)よりも優れて いること ${ }^{8,913)}$ を明らかにしている。

一方， RQ 法で作製した Al-Ni-Y系 ${ }^{19}, \mathrm{Al}-\mathrm{Mn}-\mathrm{Ce}$ 系4), Al$\mathrm{Cr}-\mathrm{Ce}-\mathrm{Co}$ 系 5 ,6合金りボン材が高強度，高耐熱強度を示すこと を報告している。また，PM法で作製した $\mathrm{Al}-\mathrm{Fe}-\mathrm{Ce}$ 系 17,19， $\mathrm{Al}$ $\mathrm{Ni}-\mathrm{Mm}\left(\mathrm{Mm}\right.$ : ミッシュメタル) 系 ${ }^{19,20)}, \mathrm{Al}-\mathrm{Ni}-\mathrm{Mm}-\mathrm{Zr}$ 系 ${ }^{21)}$ お よび $\mathrm{Al}-\mathrm{Cr}-\mathrm{Co}-\mathrm{Mm}-\mathrm{Zr}$ 系 ${ }^{22}$ 合金 $\mathrm{P} / \mathrm{M}$ 材が高強度，高耐熱，高
疲労強度を示すことも報告している.これらの事実は, $\mathrm{Al}-\mathrm{M}$ (M: 遷移金属)系合金への希土類元素の添加が機械的性質を向 上させることを示している.

従って，本報では上記の $\mathrm{Al}-\mathrm{Fe}-\mathrm{Cr}-\mathrm{Ti}$ 系および $\mathrm{Al}-\mathrm{V}-\mathrm{Fe}$ 系 合金 $\mathrm{P} / \mathrm{M}$ 材の引張強度と耐熱強度の向上を図るため, $\mathrm{Al}_{93} \mathrm{Fe}_{3} \mathrm{Cr}_{2} \mathrm{Ti}_{2}$ および $\mathrm{Al}_{94} \mathrm{~V}_{4} \mathrm{Fe}_{2}$ 合金に,ミッシュメタル $(\mathrm{Mm})$ を 1 at\% 添加した $\mathrm{Al}_{92} \mathrm{Fe}_{3} \mathrm{Cr}_{2} \mathrm{Ti}_{2} \mathrm{Mm}_{1}$ および $\mathrm{Al}_{93} \mathrm{~V}_{4} \mathrm{Fe}_{2} \mathrm{Mm}_{1}$ 合金 $\mathrm{P} / \mathrm{M}$ 材を作製し，その組織, 機械的性質を調へることを目的とした。

\section{2 試料およひ実験方法}

粉末作製用 $\mathrm{Al}_{92} \mathrm{Fe}_{3} \mathrm{Cr}_{2} \mathrm{Ti}_{2} \mathrm{Mm}_{1}$ (at\%) および $\mathrm{Al}_{93} \mathrm{~V}_{4} \mathrm{Fe}_{2} \mathrm{Mm}_{1}$ (at\%) 合金仗, $\mathrm{Al}-51.1 \mathrm{mass} \% \mathrm{Fe}, \mathrm{Al}-4.87 \mathrm{mass} \% \mathrm{Cr}, \mathrm{Al}-56.9 \mathrm{mass} \% \mathrm{~V}$ および $\mathrm{Al}-4.82$ mass\% Ti 合金, アーク溶解した $\mathrm{Al}-\mathrm{Mm}$ 合金, $\mathrm{Al}$ および $\mathrm{Cr}$ 金属を所定の組成比にて秤量後, 真空中高周波溶解 炉で作製した。粉末は高圧ガス噴霧装置 ${ }^{23}$ を使用し，約 $400 \mathrm{~g}$ 
の粉末作製用合金を Arガス雾囲気中で BNノスル付アルミナ るつほに入れ溶解後, Ar ガス圧 $9.8 \mathrm{MPa}$ にて $2 \mathrm{~mm}$ 径の BN スルより噴霧して作製した. 約 $8 \mathrm{~mm}$ 径で長さ約 $300 \mathrm{~mm}$ のP/M 材を $75 \mu \mathrm{m}$ 径以下に篩い分けした粉末を $\mathrm{Al}$ 製の缶に封入し， 押出し温度 (Te) $673 \mathrm{~K}$ ，押出し比 10:1にて作製した. Table 1 に $\mathrm{P} / \mathrm{M}$ 材の化学分析值を示す. $\mathrm{P} / \mathrm{M}$ 材の $\mathrm{Fe}$ 量は秤量組成 (Nominal composition)に比へてて約 0.5 mass\%多いが，他の元素 は秤量組成と化学分析値はほほ一致している. 不純物として $0.1 \mathrm{mass} \%$ の $\mathrm{Si}$ ，約 0.07 mass\% の O が檢出された. 粉末と $\mathrm{P} / \mathrm{M}$ 材の構造解析にはX線回折装置を, 組織観察には透過電子顕 微鏡(TEM)を，熱分析には示差走查熱量計(DSC)を用いた.室 温および高温での引張試験は, 前報 ${ }^{24)} て ゙$ 示した形状の試験片 を用いTT-CM-L型のインストロン引張試験機で行った.ヤン グ率は4204型のインストロン引張試験機と前報24)で示した形 状の試験片の中央に取り付けたひずみゲージ(共和電業製)よ り得た応力ーひずみ曲線から求めた. なお, 引張試験は各3本 つつ行った. また，室温および高温硬さはビッカース硬度計 を用いて，荷重 $100 \mathrm{~g}$ で各 10 回づつ測定した.

\section{3 実験結果および考察}

\section{1 組織}

高玨 $\mathrm{Ar}$ ガス噴第装置で得られた $\mathrm{Al}_{9_{2}} \mathrm{Fe}_{3} \mathrm{Cr}_{2} \mathrm{Ti}_{2} \mathrm{Mm}_{1}$ および $\mathrm{Al}_{93} \mathrm{~V}_{4} \mathrm{Fe}_{2} \mathrm{Mm}_{1}$ 合金粉末はほほ球状の形態を持ち，平均粒径は 約 $30 \mu \mathrm{m}$ 径である. 押出し成形材 (P/M 材) は $75 \mu \mathrm{m}$ 径以下 ( 75 $\mu \mathrm{m} \geqq) に$ 節い分けした粉末を用いて作製した。これら粉末の X線回折図形を Fig.1 に示す. $\mathrm{Al}_{92} \mathrm{Fe}_{3} \mathrm{Cr}_{2} \mathrm{Ti}_{2} \mathrm{Mm}_{1}$ 合金粉末は fcc$\mathrm{Al}(\mathrm{Al})+$ 準結晶 $(\mathrm{Q} . \mathrm{C}$. $)+\mathrm{Al}_{13} \mathrm{Cr}_{2}$ 化合物 $+\mathrm{Al}_{13} \mathrm{Fe}_{4}$ 化合物 $+\mathrm{Al}_{4} \mathrm{Ce}$ 化合物, $\mathrm{Al}_{93} \mathrm{~V}_{4} \mathrm{Fe}_{2} \mathrm{Mm}_{1}$ 合金粉末は $\mathrm{Al}+\mathrm{Al}_{11} \mathrm{~V}$ 化合物の複相であ る. $\mathrm{Al}_{93} \mathrm{~V}_{4} \mathrm{Fe}_{2} \mathrm{Mm}_{1}$ 合金粉末中の $\mathrm{Fe}$ と $\mathrm{Mm}$ は $\mathrm{Al}$ と $\mathrm{Al}_{11} \mathrm{~V}$ 化合物 中に固溶しているものと考えられる. $\mathrm{Al}_{92} \mathrm{Fe}_{3} \mathrm{Cr}_{2} \mathrm{Ti}_{2} \mathrm{Mm}_{1}$ 合金粉 末では, $\mathrm{Mm}$ を含まない $\mathrm{Al}_{9} \mathrm{Fe}_{3} \mathrm{Cr}_{2} \mathrm{Ti}_{2}$ 合金粉末》に比べて，化 合物の生成を示す回折ピークが多く観察され，準結晶の回折 ピーク強度は極めて弱くなる. $\mathrm{Al}_{93} \mathrm{~V}_{4} \mathrm{Fe}_{2} \mathrm{Mm}_{1}$ 合金粉末では， $\mathrm{Mm}$ を含まない $\mathrm{Al}_{94} \mathrm{~V}_{4} \mathrm{Fe}_{2}$ 合金粉末 ${ }^{12)}$ で観察された準結晶の回 折ビークは観察されなくなる. 同様のX線回折図形は押出し 成形材 (PM材)においても観察される。これらは, $\mathrm{Al}_{9} \mathrm{Fe}_{3} \mathrm{C}_{2} \mathrm{Ti}_{2}$ および $\mathrm{Al}_{94} \mathrm{~V}_{4} \mathrm{Fe}_{2}$ 合金に $1 \mathrm{at} \% \mathrm{Mm}$ を添加すると準結晶の生成が 抑制されることを示している.
Fig.2 は $\mathrm{Al}_{92} \mathrm{Fe}_{3} \mathrm{Cr}_{2} \mathrm{Ti}_{2} \mathrm{Mm}_{1}$ 合金 $\mathrm{P} / \mathrm{M}$ 材の TEM 明視野像 $(\mathrm{a} \sim \mathrm{d})$, 電子線回折像 $(\mathrm{e} \sim \mathrm{h})$ である. 正20面体準結晶の生成を示す 5 回, 3回および2回対称性の回折斑点が観察される.しかし試料を 少し移動させると Fig.3の明視野像 (a)に示すように析出物が 多くなり, 電子回折像には微細な析出物を示す回折リング(b) と析出物の回折斑点 (c) が観察されるようになる. 析出物は Fig.1のX線回折結果から， $\mathrm{Al}_{13} \mathrm{Cr}_{2}, \mathrm{Al}_{13} \mathrm{Fe}_{4}$ および $\mathrm{Al}_{4} \mathrm{Ce}$ 化合物 と思われる。 Fig.4 は $\mathrm{Al}_{93} \mathrm{~V}_{4} \mathrm{Fe}_{2} \mathrm{Mm}_{1}$ 合金 $\mathrm{P} / \mathrm{M}$ 材の TEM 明視野 像 (a), 電子線回折像 $(b, c, d)$ である．明視野像には $100 〜 200 \mathrm{~nm}$ の析出物が観察され, 電子線回折図形には $\mathrm{Al}+\mathrm{Al}_{11} \mathrm{~V}$ 化合物の 複相組織を示す回折斑点と回折リングか観察される. 電子線 回折図形に，準結晶の析出を示す回折斑点が観察されないこ とから, $\mathrm{Al}_{94} \mathrm{~V}_{4} \mathrm{Fe}_{2}$ 合金 $\mathrm{P} / \mathrm{M}$ 材への $\mathrm{Mm}$ の添加は準結晶の生成 が抑制されたことを示している.

\section{2 熱的性質}

Fig.5は粒径が $75 \mu \mathrm{m}$ 以下の粉末を用いて作製した $\mathrm{Al}_{92} \mathrm{Fe}_{3} \mathrm{Cr}_{2}$ $\mathrm{Ti}_{2} \mathrm{Mm}_{1}$ 合金 $\mathrm{P} / \mathrm{M}$ 材 (AFCTMm-75P/M) および $\mathrm{Al}_{93} \mathrm{~V}_{4} \mathrm{Fe}_{2} \mathrm{MMm}_{1}$ 合 金P/M 材 (AVFMm-75P/M) の DSC曲線である．図中，750 K 付近から現れるプロードなピークはP/M(材)中に析出している 準結晶の分解開始温度 $\left(T_{d}\right)$ に対応するものである.これは, $\mathrm{Min}$ を含まない $\mathrm{Al}_{93} \mathrm{Fe}_{3} \mathrm{Cr}_{2} \mathrm{Ti}_{2}$ 合金 $\mathrm{P} / \mathrm{M}$ 材の $\mathrm{T}_{\mathrm{d}}$ よりも $40 \mathrm{~K}$ 低くなっ

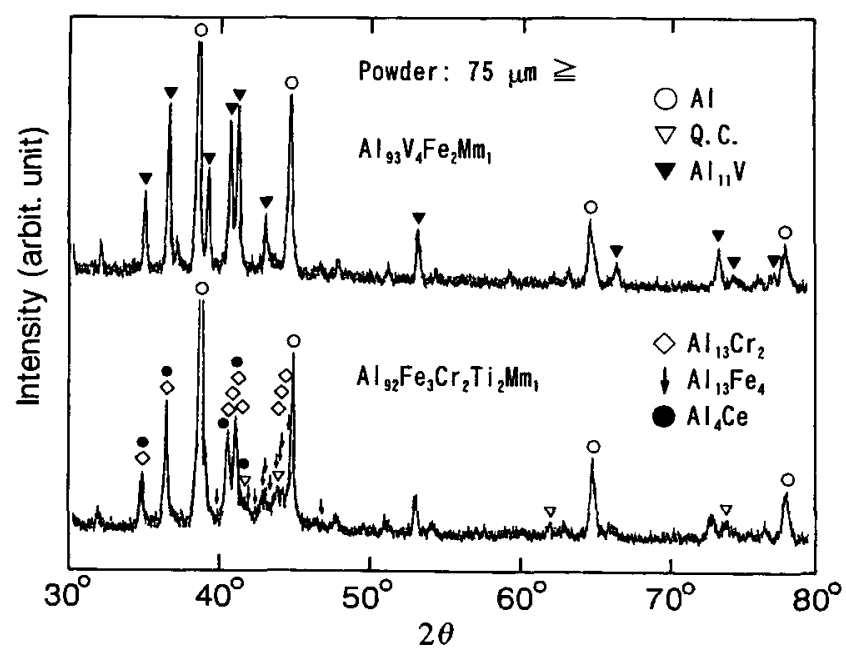

Fig.1 X-ray diffraction patterns of gas atomized $\mathrm{Al}_{92} \mathrm{Fe}_{3} \mathrm{Cr}_{2} \mathrm{Ti}_{2} \mathrm{Mm}_{1}$ and $\mathrm{Al}_{93} \mathrm{~V}_{4} \mathrm{Fe}_{2} \mathrm{Mm}_{1}$ alloy powders with the size of $\leqq 75 \mu \mathrm{m}$.

Table 1 Composition of $\mathrm{P} / \mathrm{M} \mathrm{Al} \mathrm{Al}_{2} \mathrm{Fe}_{3} \mathrm{Cr}_{2} \mathrm{Ti}_{2} \mathrm{Mm}_{1}$ alloy and $\mathrm{Al}_{93} \mathrm{~V}_{4} \mathrm{Fe}_{2} \mathrm{Mm}_{1}$ alloy by chemical analysis.

\begin{tabular}{|c|c|c|c|c|c|c|c|c|c|c|}
\hline $\mathrm{P} / \mathrm{M}$ Alloys & $\mathrm{Al}$ & $\mathrm{Fe}$ & $\mathrm{Cr}$ & $\mathrm{V}$ & $\mathrm{Ti}$ & $\mathrm{Ce}$ & $\mathrm{La}$ & $\mathrm{Nd}$ & $\mathrm{Si}$ & $\mathrm{O}$ \\
\hline $\mathrm{Al}_{92} \mathrm{Fe}_{3} \mathrm{Cr}_{2} \mathrm{Ti}_{2} \mathrm{Mm}_{1}$ & 82.7 & 5.9 & 3.6 & - & 3.2 & 2.6 & 1.2 & 0.7 & 0.1 & 0.06 \\
$(\mathrm{Nominal})$ & $(83.0)$ & $(5.6)$ & $(3.5)$ & $(-)$ & $(3.2)$ & $(2.5)$ & $(1.3)$ & $(0.7)$ & $(0.1)$ & $(-)$ \\
\hline $\mathrm{Al}_{93} \mathrm{~V}_{4} \mathrm{Fe}_{2} \mathrm{Mm}_{1}$ & 83.7 & 4.3 & - & 6.8 & - & 2.7 & 1.4 & 0.8 & 0.1 & 0.08 \\
(Nominal) & $(83.1)$ & $(3.7)$ & $(-)$ & $(6.8)$ & $(-)$ & $(2.5)$ & $(1.3)$ & $(0.7)$ & $(0.1)$ & $(-)$ \\
\hline
\end{tabular}




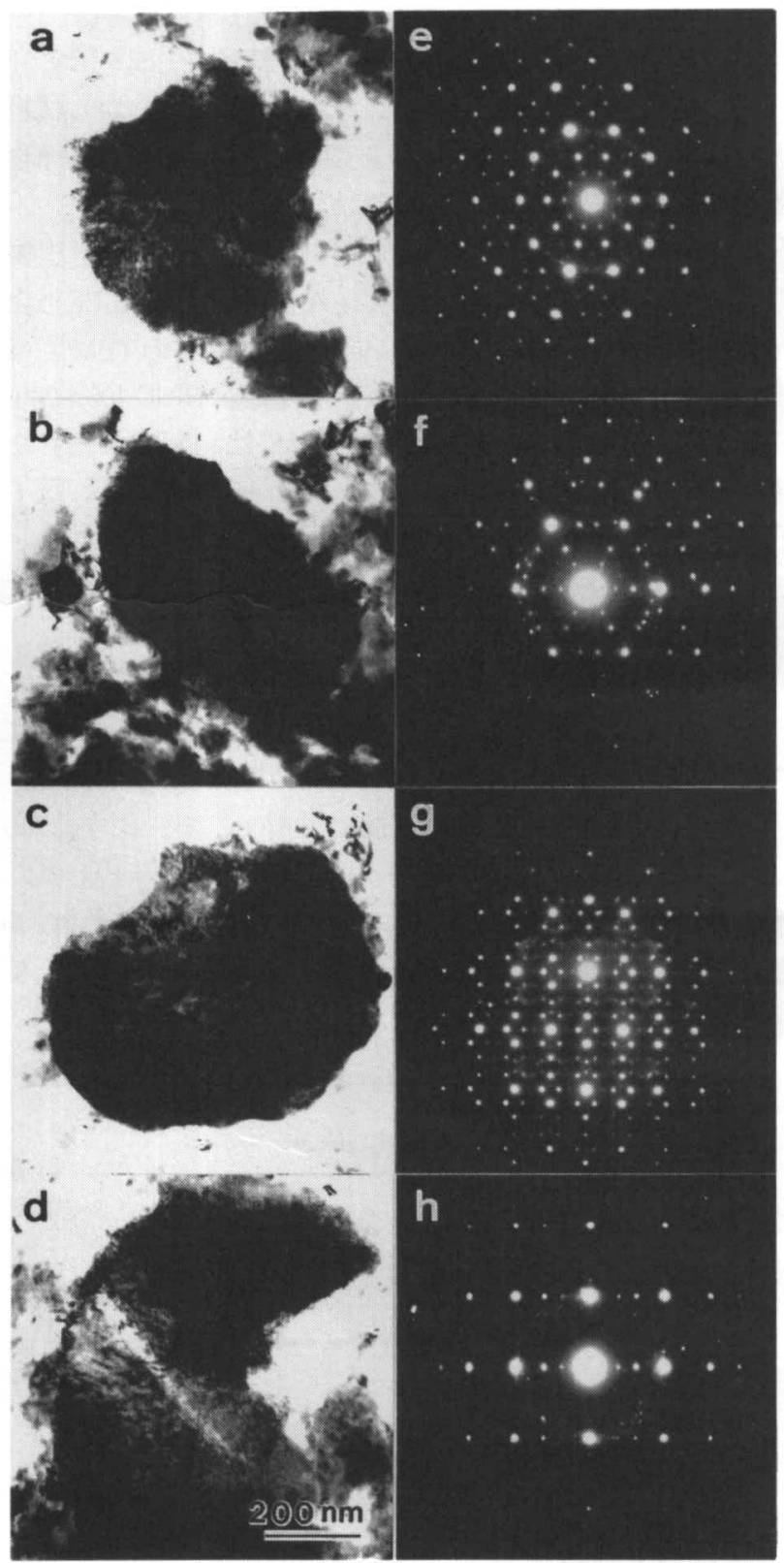

Fig.2 Bright-field electron micrographs $(\mathrm{a} \sim \mathrm{d})$ and selected-area electron diffraction patterns $(\mathrm{e} \sim \mathrm{h})$ of the $\mathrm{P} / \mathrm{M} \mathrm{Al}_{92} \mathrm{Fe}_{3} \mathrm{Cr}_{2} \mathrm{Ti}_{2} \mathrm{Mm}_{1}$ alloy.

ている.このことは, 上述したように $\mathrm{Mm} か ゙ \mathrm{Al}_{92} \mathrm{Fe}_{3} \mathrm{Cr}_{2} \mathrm{Ti}_{2} \mathrm{Mm}_{1}$ 合金 $\mathrm{P} / \mathrm{M}$ 材中の準結晶生成を抑制することと関連している. 一方, AVFMm-75P/M では発熱ピークは観察されず, P/M 材 中に準結晶が生成していないことを示している。

\section{3 機械的性質}

Fig.6は AFCTMm-75P/M と AVFMm-75P/M の室温 (R.T.) お よび $573 \mathrm{~K} て ゙ ~ 100$ 時間保持後 $(573 \mathrm{~K}, 100 \mathrm{~h})$ の応力ーひずみ曲 線である. 室温(R.T.)における塑性変形は, AFCTMm-75P/M では僅かに観察されるが, AVFMm-75P/Mでは観察されない。 この塑性変形は, 室温よりも $573 \mathrm{~K}, 100 \mathrm{~h}$ の方が大きくなって いる. Table 2 はひずみ速度 $4.0 \times 10^{-4} \mathrm{~s}^{-1}$ での引張試験から得た

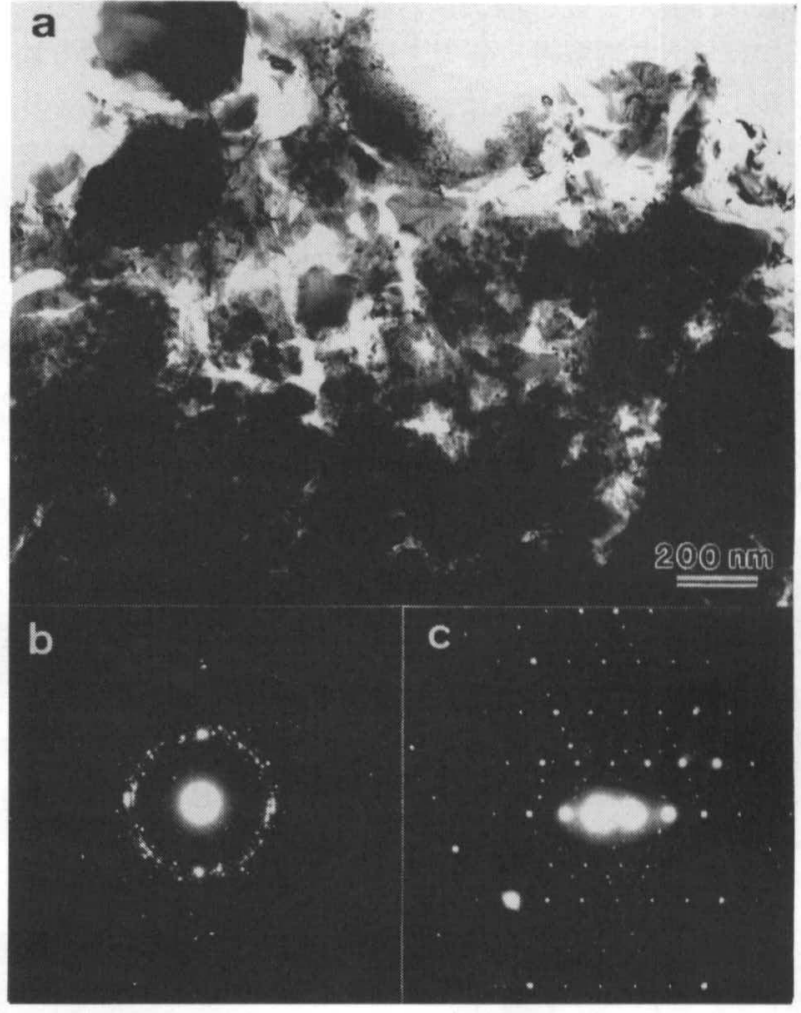

Fig.3 Bright-field electron micrograph (a) and selected-area diffraction patterns ( $\mathrm{b}$ and $\mathrm{c}$ ) of the $\mathrm{P} / \mathrm{M} \mathrm{Al}{ }_{92} \mathrm{Fe}_{3} \mathrm{C}_{2} \mathrm{Ti}_{2} \mathrm{Mm}_{1}$ alloy.

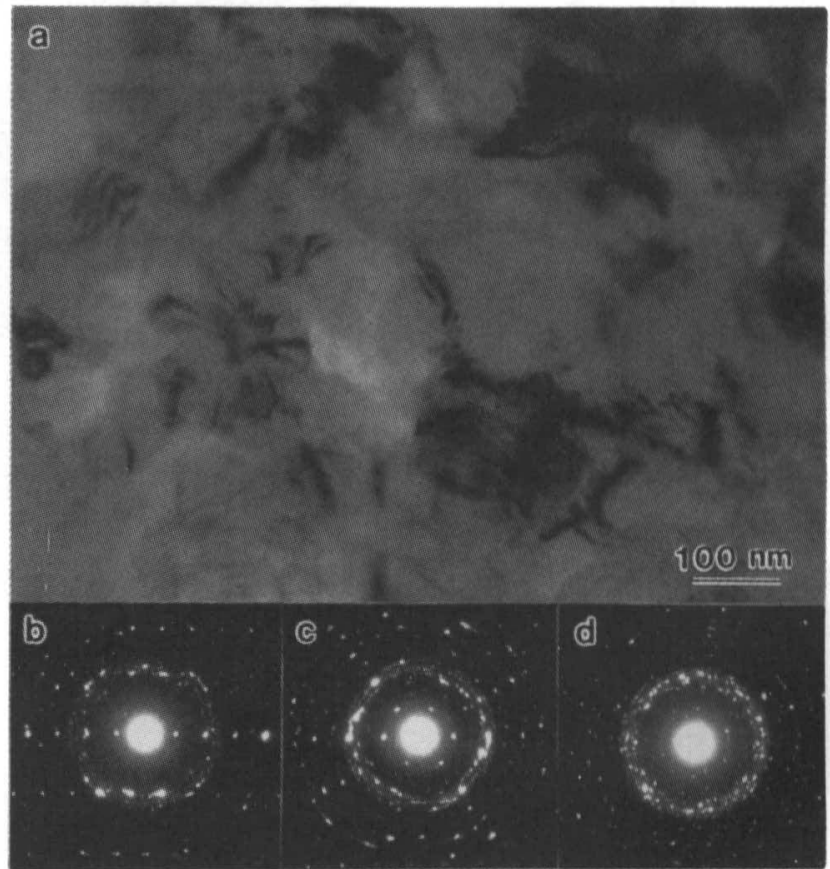

Fig.4 Bright-field electron micrographs (a) and selected-area diffraction patterns $(b, c$ and $d)$ of the $\mathrm{P} / \mathrm{M} \mathrm{Al}_{93} \mathrm{~V}_{4} \mathrm{Fe}_{2} \mathrm{Mm}_{1}$ alloy.

AFCTMm-75P/M, AVFMm-75P/Mの最大引張強度 $\left(\sigma_{\text {UTS }}\right), 0.2 \%$ 耐力 $\left(\sigma_{0.2}\right)$, 伸び $\left(\varepsilon_{\mathrm{P}}\right)$ ヤング率 $(\mathrm{E})$ とビッカース硬さ $(\mathrm{Hv})$ をま 


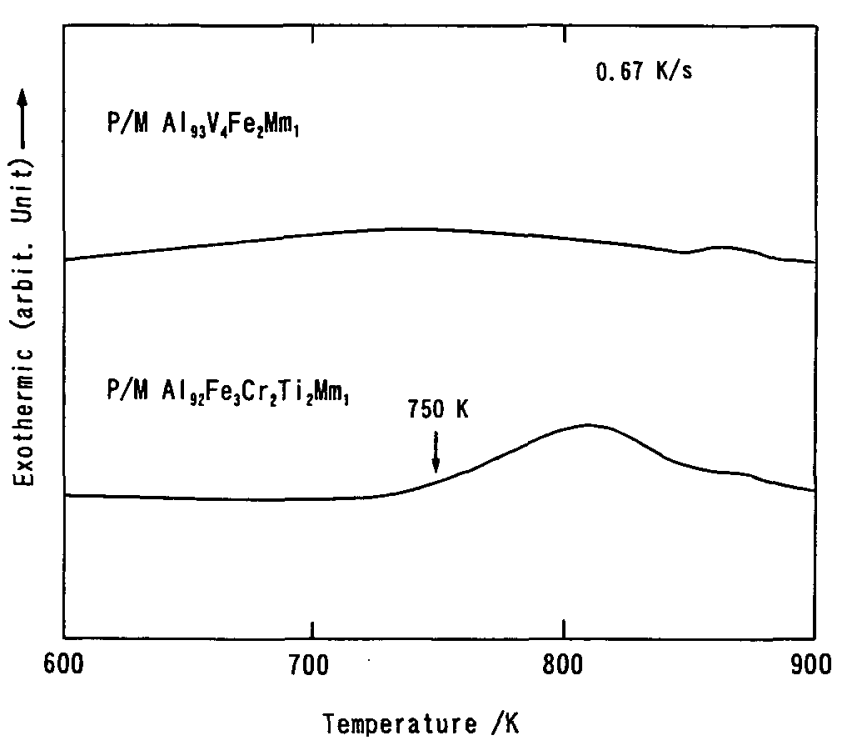

Fig.5 Differential scanning calorimetry (DSC) curves of the $\mathrm{Al}_{92} \mathrm{Fe}_{3} \mathrm{Cr}_{2} \mathrm{Ti}_{2} \mathrm{Mm}_{1}$ and $\mathrm{Al}_{93} \mathrm{~V}_{4} \mathrm{Fe}_{2} \mathrm{Mm}_{1}$ alloys.

とめている．比較材料として $26 \mu \mathrm{m}$ 以下の粉末を用いて作製 した $\mathrm{Al}_{93} \mathrm{Fe}_{3} \mathrm{Cr}_{2} \mathrm{Ti}_{2}$ 合金 $\mathrm{P} / \mathrm{M}$ 材 (AFCT-26P/M)，125 $\mu \mathrm{m}$ 以下の粉 末を用いて作製した $\mathrm{Al}_{3} \mathrm{Fe}_{3} \mathrm{Cr}_{2} \mathrm{Ti}_{2}$ 合金 P/M材 (AFCT-125P/M), $26 \mu \mathrm{m}$ 以下の粉末を用いて作製した $\mathrm{Al}_{94} \mathrm{~V}_{4} \mathrm{Fe}_{2}$ 合金 $\mathrm{P} / \mathrm{M}$ 材 (AVF26P/M) および超々ジュラルミン (7075-T6) の結果も示してあ る. AFCTMm-75P/M の $\sigma_{\text {UTS }}, \sigma_{0.2}, \mathrm{E}$ および $\mathrm{Hv}$ は $\mathrm{Mm}$ を含ま ない AFCT-26P/M, AFCT-125P/Mや7075-T6よりも大きいが， $\varepsilon_{\mathrm{P}}$ は極めて小さい。しかしながら， $\sigma_{\mathrm{USS}}$ は $\mathrm{Al}$ 合金の開発目標 值 ${ }^{25)}$ である引張強度 $700 \mathrm{MPa}$ に近づいており,この強度を劣 化させることなく，伸びを大きくする合金探査が今後の検討 課題である．AVF-26P/M の $\varepsilon_{\mathrm{P}}$ は 4.5\%であるが， Mm を含む AVFMm-75P/M は0\%になる. AVFMm-75P/Mの $\sigma_{\text {uns }}$ は, AVF$26 \mathrm{P} / \mathrm{M} よ り も$ 約 $60 \mathrm{MPa}$ 小さい。これらは, $\mathrm{Al}_{94} \mathrm{~V}_{4} \mathrm{Fe}_{2}$ 合金に $\mathrm{Mm}$ を添加しても，引張強度や伸びの向上に効果がないこと を示している.

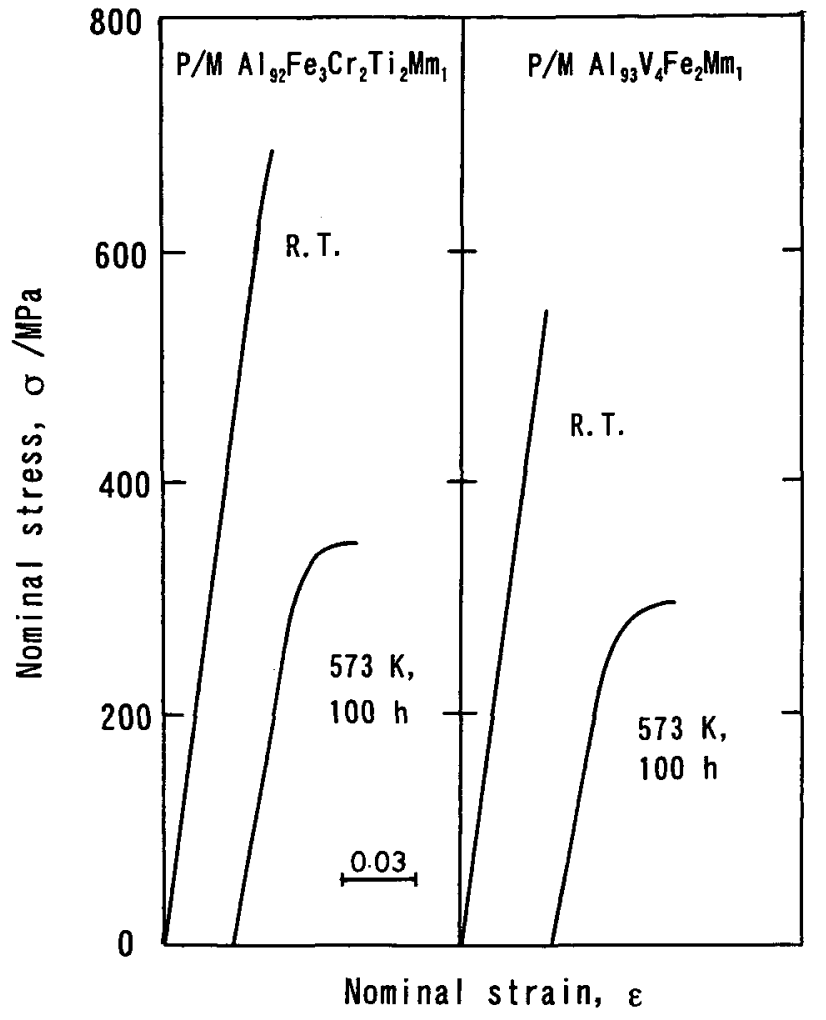

Fig.6 Tensile stress-strain curves of the $\mathrm{P} / \mathrm{M} \mathrm{Al}_{92} \mathrm{Fe}_{3} \mathrm{Cr}_{2} \mathrm{Ti}_{2} \mathrm{Mm}_{1}$ and $\mathrm{Al}_{93} \mathrm{~V}_{4} \mathrm{Fe}_{2} \mathrm{Mm}_{1}$ alloys at room temperature (R.T.) and at $573 \mathrm{~K}$ after holding for 100 hours at $573 \mathrm{~K}$.

\section{4 高温硬さおよび耐熱強度}

Fig.7は $\mathrm{Al}_{92} \mathrm{Fe}_{3} \mathrm{Cr}_{2} \mathrm{Ti}_{2} \mathrm{Mm}_{1}$ 合金 P/M 材 (AFCTMm-75P/M) のア ルゴン雾囲気中で測定したビッカース硬さの温度依存性である。 比較材料として $\mathrm{Mm}$ を含まない AFCT-26P/M および AFCT125P/Mの結果も示してある. AFCTMm-75P/M の室温硬さは 230であり， AFCT-26P/Mの 192，7075-T6アルミニウム合金 の $190^{24)}, \mathrm{Al}-\mathrm{V}-\mathrm{Fe}$ 合金 P/M 材の $190^{12)}$ より大きい。硬さは温 度の上昇と共に緩やかに隇少し，573Kでは130であり，AFCT-

Table 2 Mechanical properties of the $\mathrm{P} / \mathrm{M} \mathrm{Al} \mathrm{g}_{2} \mathrm{Fe}_{3} \mathrm{Cr}_{2} \mathrm{Ti}_{2} \mathrm{Mm}_{1}$ and $\mathrm{Al}_{93} \mathrm{~V}_{4} \mathrm{Fe}_{2} \mathrm{Mm}_{1}$ alloys at room temperature. The data of the $\mathrm{P} / \mathrm{M} \mathrm{Al}_{93} \mathrm{Fe}_{3} \mathrm{Cr}_{2} \mathrm{Ti}_{2}$ alloy, $\mathrm{P} / \mathrm{M} \mathrm{Al}{ }_{94} \mathrm{Ve}_{4} \mathrm{Fe}_{2}$ alloy and 7075-T6 aluminum alloy are also shown for comparison.

\begin{tabular}{|l|c|c|c|c|c|c|}
\hline \multicolumn{1}{|c|}{ Designation } & Alloy & $\sigma_{U T S} / \mathrm{MPa}$ & $\sigma_{0.2} / \mathrm{MPa}$ & $\varepsilon_{\mathrm{P}} / \%$ & $\mathrm{E} / \mathrm{GPa}$ & $\mathrm{Hv}$ \\
\hline AFCTMm-75P/M & $\mathrm{Al}_{92} \mathrm{Fe}_{3} \mathrm{Cr}_{2} \mathrm{Ti}_{2} \mathrm{Mm}_{1}$ & $680 \pm 13$ & $670 \pm 10$ & $0.3 \pm 0.1$ & $91 \pm 3$ & $230 \pm 3$ \\
\hline AFCT-26P/M & $\mathrm{Al}_{93} \mathrm{Fe}_{3} \mathrm{Cr}_{2} \mathrm{Ti}_{2}$ & $658 \pm 9$ & $545 \pm 14$ & $4.4 \pm 0.5$ & $85 \pm 2$ & $192 \pm 3$ \\
\hline AFCT-125P/M & $\mathrm{Al}_{93} \mathrm{Fe}_{3} \mathrm{Cr}_{2} \mathrm{Ti}_{2}$ & 541 & 460 & 7.3 & 83 & 165 \\
\hline AVFMm-75P/M & $\mathrm{Al}_{93} \mathrm{~V}_{4} \mathrm{Fe}_{2} \mathrm{Mm}_{1}$ & $530 \pm 20$ & - & 0 & 93 & $220 \pm 1$ \\
\hline AVF-26P/M & $\mathrm{Al}_{94} \mathrm{Ve}_{4} \mathrm{Fe}_{2}$ & 585 & 490 & 4.5 & 85 & 190 \\
\hline 7075-T6 & - & 600 & 550 & 10.7 & 70 & 190 \\
\hline
\end{tabular}




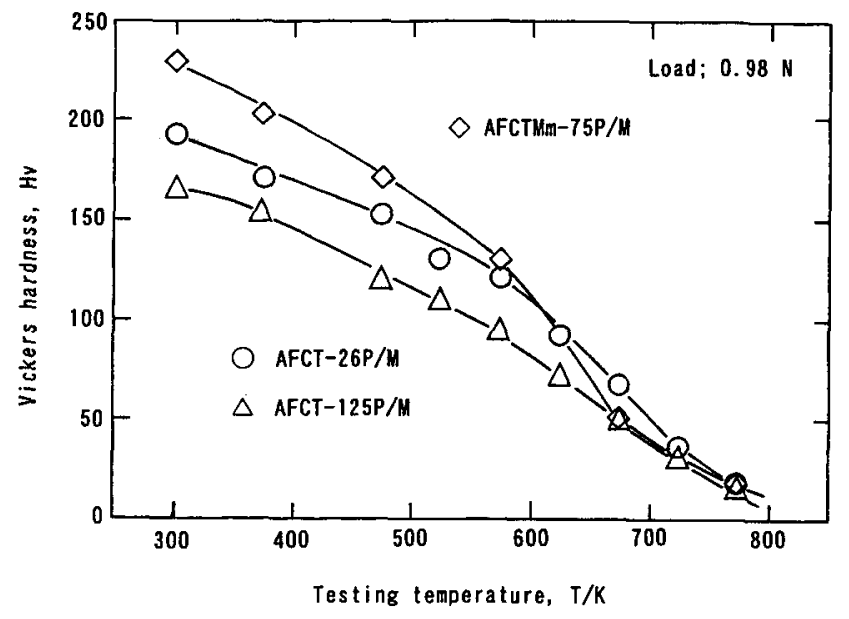

Fig.7 The Vickers hardness as a function of temperature for the $\mathrm{P} / \mathrm{M}$ $\mathrm{Al}_{92} \mathrm{Fe}_{3} \mathrm{Cr}_{2} \mathrm{Ti}_{2} \mathrm{Mm}_{1}$ alloy (AFCTMm-75P/M) produced by extruding atomized powders with the size of $\leqq 75 \mu \mathrm{m}$. The data of the $\mathrm{P} / \mathrm{M} \mathrm{Al} \mathrm{Al}_{3} \mathrm{Fe}_{3} \mathrm{Cr}_{2} \mathrm{Ti}_{2}$ alloy (AFCT-26P/M) produced by extruding atomized powders with the size of $\leqq 26 \mu \mathrm{m}$ (AFCT-26P/M) and P/M Al${ }_{93} \mathrm{Fe}_{3} \mathrm{Cr}_{2} \mathrm{Ti}_{2}$ alloy (AFCT-125P/M) produced by extruding atomized powders with the size of $\leqq$ $125 \mu \mathrm{m}$ are also shown for comparison.

26PMの128よりも大きいが, 623Kになると，硬さは52になり， AFCT-26P/Mの68よりも小さくなる.また図から， AFCTMm75P/M の硬さの温度減少率は Mm を含まない AFCT-26P/M や AFCT-125P/Mよりも大きい。これらの現象は3.1および3.2項 で記述したように, AFCTMm-75P/Mに含まれている熱的安定 性をもつ準結晶の量か AFCT-26P/M や AFCT-125P/M よりも 少ないことに起因していると考えられる。

Table 3 は $7 \times 10^{-3} \mathrm{~Pa}$ の真空中において, $573 \mathrm{~K}$ まで 30 分で 加熱, 100 時間保持後, ひずみ速度 $4.0 \times 10^{-4} \mathrm{~s}^{-1}$ での引張試験 から得た Mm 含む AFCTMm-75P/M, AVFMm-75P/M の $\sigma_{\text {UTS, }}$ $\sigma_{02}$ および $\varepsilon_{\mathrm{P}}$ をまとめている. 比較材料として $\mathrm{Mm}$ を含まない AFCT-26P/M, AFCT-125P/M, AVF-26P/Mの結果も示してある. なお, $\mathrm{AVF}-26 \mathrm{P} / \mathrm{M}$ の保持時間は 5 分である. $\mathrm{Al}_{93} \mathrm{Fe}_{3} \mathrm{Cr}_{2} \mathrm{Ti}_{2}$ 合 金の Al を 1at\%Mm で置換した AFCTMm-75P/M は, Mm を含 まないAFCT-26P/Mよりも押出し成型に用いる粉末形状が大 きいにもかかわらず, 耐熱強度が大きい.しかしながら, 伸
びは極めて小さくなる．このような傾向は，AVFMm-75P/M と AVF-26P/M の関係でも得られる。これらのことは， $\mathrm{Al}_{93} \mathrm{Fe}_{3} \mathrm{Cr}_{2} \mathrm{Ti}_{2}$ および $\mathrm{Al}_{94} \mathrm{~V}_{4} \mathrm{Fe}_{2}$ 合金に $\mathrm{Mm}$ を添加すると，耐熱 強度は向上するが，伸びは小さくなることを示している。

\section{4 ま と め}

高圧ガス噴霧法で作製した $\mathrm{Al}_{92} \mathrm{Fe}_{3} \mathrm{Cr}_{2} \mathrm{Ti}_{2} \mathrm{Mm}_{1}$ および $\mathrm{Al}_{93} \mathrm{~V}_{4} \mathrm{Fe}_{2} \mathrm{Mm}_{1}$ 合金粉末を $75 \mu \mathrm{m}$ 以下 $(75 \mu \mathrm{m} \geqq)$ に篩い分けし た後，この粉末から押出し材 $(\mathrm{P} / \mathrm{M}$ 材)を作製し，組織，機械 的性質を調へ，下記の知見を得た。

(1) $\mathrm{Al}_{93} \mathrm{Fe}_{3} \mathrm{Cr}_{2} \mathrm{Ti}_{2}$ および $\mathrm{Al}_{94} \mathrm{~V}_{4} \mathrm{Fe}_{2}$ 合金に $1 \mathrm{at} \%$ のミッシュメ夕 ル $(\mathrm{Mm})$ を添加すると，準結晶の生成が抑制される.

(2) 室温の機械的性質は, $\mathrm{Al}_{92} \mathrm{Fe}_{3} \mathrm{Cr}_{2} \mathrm{Ti}_{2} \mathrm{Mm}_{1}$ 合金 $\mathrm{P} / \mathrm{M}$ 材 $(\mathrm{AFCTMm}-75 \mathrm{P} / \mathrm{M})$ では最大引張強度 $\left(\sigma_{\text {UIs }}\right)=680 \pm 13 \mathrm{MPa}$, $0.2 \%$ 耐力 $\left(\sigma_{0.2}\right)=670 \pm 10 \mathrm{MPa},\left(\varepsilon_{\mathrm{P}}\right)=0.4 \pm 0.1 \%$ ，ヤング率 (E) $=91 \pm 4 \mathrm{GPa}$ およびビッカース硬さ $(\mathrm{Hv})=232 \pm 2 て ゙ あ り$, $\mathrm{Al}_{93} \mathrm{~V}_{4} \mathrm{Fe}_{2} \mathrm{Mm}_{1}$ 合金 $\mathrm{P} / \mathrm{M}$ 材 $(\mathrm{AVFMm}-75 \mathrm{P} / \mathrm{M})$ では $\sigma_{\mathrm{UTS}}=530$

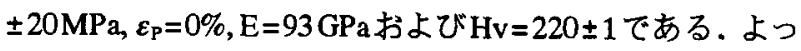
て $\mathrm{Al}_{93} \mathrm{Fe}_{3} \mathrm{Cr}_{2} \mathrm{Ti}_{2}$ および $\mathrm{Al}_{94} \mathrm{~V}_{4} \mathrm{Fe}_{2}$ 合金に，希土類元素である ミッシュメタル $(\mathrm{Mm})$ を添加すると， $\sigma_{\mathrm{UTS}}, \sigma_{0.2}, \mathrm{E}, \mathrm{Hv}$ は大 きくなるが, $\varepsilon_{\mathrm{P}}$ は極めて小さくなる.

(3) 温度上昇によるAFCTMm-75P/MおよびAVFMm-75P/M のビッカース硬さ $(\mathrm{Hv})$ の減少率は， Mm を添加しない $\mathrm{Al}_{93} \mathrm{Fe}_{3} \mathrm{Cr}_{2} \mathrm{Ti}_{2}$ 合金 $\mathrm{P} / \mathrm{M}$ 材 (AFCT-26P/M) $\mathrm{Al}_{94} \mathrm{~V}_{4} \mathrm{Fe}_{2}$ 合金 $\mathrm{P} / \mathrm{M}$ 材(AVF-26P/M) よりも大きい.

(4) $573 \mathrm{~K}, 100 \mathrm{~h}$ 保持後の機械的性質は, AFCTMm-75P/Mでは $\sigma_{\text {UTS }}=347 \pm 5 \mathrm{MPa}, \sigma_{0.2}=315 \pm 6 \mathrm{MPa}, \varepsilon_{\mathrm{P}}=1.8 \pm 0.3 \%$ であり, AVFMm-75P/M では $\sigma_{\text {Urs }}=294 \pm 4 \mathrm{MPa}, \sigma_{0.2}=252 \pm 2 \mathrm{MPa}$, $\varepsilon_{\mathrm{P}}=2.8 \pm 0.3 \%$ である。

\section{謝辞}

粉末作製用合金の高周波溶解，引張試験，透過電子顕微鏡 観察, 化学分析に御協力頂いた東北大学金属材料研究所 元吉 井勇助手, 元末永裕技官, 伊藤俊技官, 元庄子勉助手, 元 竹内正邦助手, 元今野栄行助手に感謝致します. また, 本研 究の一部は(財)軽金属奖学会の研究助成金で行われたことを 記し，謝意を表します。

Table 3 Mechanical properties of the $\mathrm{P} / \mathrm{M} \mathrm{Al}{ }_{92} \mathrm{Fe}_{3} \mathrm{Cr}_{2} \mathrm{Ti}_{2} \mathrm{Mm}_{1}$ and $\mathrm{Al}_{93} \mathrm{~V}_{4} \mathrm{Fe}_{2} \mathrm{Mm}_{1}$ alloys after holding for 100 hours at $573 \mathrm{~K}$. The data of the $\mathrm{P} / \mathrm{M} \mathrm{Al}{ }_{93} \mathrm{Fe}_{3} \mathrm{Cr}_{2} \mathrm{Ti}_{2}$ and $\mathrm{Al}_{94} \mathrm{Ve}_{4} \mathrm{Fe}_{2}$ alloys are also shown for comparison.

\begin{tabular}{|l|c|c|c|c|}
\hline \multicolumn{1}{|c|}{ Designation } & Alloy & $\sigma_{U T S} / \mathrm{MPa}$ & $\sigma_{0.2} / \mathrm{MPa}$ & $\varepsilon_{\mathrm{P}} / \%$ \\
\hline AFCTMm-75P/M & $\mathrm{Al}_{92} \mathrm{Fe}_{3} \mathrm{Cr}_{2} \mathrm{Ti}_{2} \mathrm{Mm}_{1}$ & $347 \pm 5$ & $315 \pm 6$ & $1.8 \pm 0.3$ \\
\hline AFCT-26P/M & $\mathrm{Al}_{93} \mathrm{Fe}_{3} \mathrm{Cr}_{2} \mathrm{Ti}_{2}$ & 336 & 312 & 2.6 \\
\hline AFCT-125P/M & $\mathrm{Al}_{93} \mathrm{Fe}_{3} \mathrm{Cr}_{2} \mathrm{Ti}_{2}$ & 278 & 260 & 7.4 \\
\hline AVFMm-75P/M & $\mathrm{Al}_{93} \mathrm{~V}_{4} \mathrm{Fe}_{2} \mathrm{Mm}_{1}$ & $294 \pm 4$ & $252 \pm 2$ & $2.8 \pm 0.3$ \\
\hline AVF-26P/M & $\mathrm{Al}_{94} \mathrm{Ve}_{4} \mathrm{Fe}_{2}$ & 291 & 277 & 6.0 \\
\hline
\end{tabular}




\section{文献}

1) A.Inoue, H.M.Kimura and T.Masumoto: "Formation, Thermal Stability and Electrical Resistivity of ...", J. Mater. Sci., 22(1987) 1758-1768.

2) 竹内伸: "準結晶の機械的性質", 鉄と鋼, (1992)1517-1522.

3) D.Shechtman, I.A.Blech, D.Gratias and J.W.Cahn: "Metallic Phase with Long-Range Orientational Order ..", Phys. Rev. Lett., 53(1984)1951-1953.

4) A.Inoue, M.Watanabe, H.M.Kimura, F.Takahashi, A.Nagata and T.Masumoto: "High Mechanical Strength of...", Mater. Trans., JIM, 33(1987)723-729.

5) A.Inoue, H.M.Kimura, K.Sasamori and T.Masumoto: "Ultrahigh Strength Rapidly Solidified $\mathrm{Al}_{96-\mathrm{x}} \mathrm{Cr}_{3} \mathrm{Ce}_{1} \mathrm{Co}_{x} \cdots "$, Mater. Trans., JIM, 35(1987)85-94.

6) A.Inoue, H.M.Kimura, K.Sasamori and T.Masumoto: "Microstructure and Mechanical Properties...", Mater. Trans., JIM, 36(1995)6-15.

7) 木村久道, 并上明久, 笹森賢一郎, 喜多和彦: "準結晶を含 む $\mathrm{Al}-6.3 \% \mathrm{Fe}-3.8 \% \mathrm{Cr}-3.3 \% \mathrm{Ti}$ 合金 $\mathrm{P} / \mathrm{M}$ 材の組織と機械的 性質 ", 軽金属 , 48(1998)263-268.

8) 木村久道, 井上明久, 笹森賢一郎, 喜多和彦, 大野木輝明: " 準結晶を含む $\mathrm{Al}-(\mathrm{Cr}, \mathrm{Mn})-\mathrm{Fe}-(\mathrm{Ti}, \mathrm{V})$ 系 4 元合金 P/M 材の 組織と機械的性質", 軽金属, 48(1998)494-500.

9) 木村久道, 井上明久, 笹森賢一郎, 加藤晃, 大野木輝明, 喜 多和彦: " 準結晶粒子分散 Al-Fe-M-Ti (M=V, Cr, Mn) 合 金 P/M 材の組織と耐熱強度 ", 粉体および粉末治金, 46 (1999)1321-1326.

10）笹森賢一郎, 木村久道,井上明久,村上義弘: " 液体急冷 $\mathrm{A}$ $\mathrm{Fe}-\mathrm{Ti}-\mathrm{M}(\mathrm{M}=\mathrm{V}, \mathrm{Cr}, \mathrm{Mn})$ 合金の組織と機械的性質 ", 粉体 および粉末治金, 47(2000)417-422.

11) 木村久道, 井上明久, 笹森賢一郎, 河村能人: "メカ二カル グラインテング処理したAl-7.9\%V-4\%Fe合金粉末の押出 成形と耐熱強度 ", 軽金属 , 47(1997)487-492.

12) 木村久道, 井上明久, 笹森賢一郎, 河村能人: " 準結晶を含 むガス噴霧 $\mathrm{Al}-7.8 \% \mathrm{~V}-4 \% \mathrm{Fe}$ 合金粉末の押出成形と耐熱強 度 ", 軽金属 , 47(1997)539-544.

13) 木村久道, 并上明久，笹森賢一郎："汻結晶を含む Al一
7.8\% V-4\%Fe 合金 P/M 材の組織と耐摩耗性 ", 軽金属 , 48 (1998)127-131.

14) 木村久道, 井上明久, 笹森賢一郎, 河村能人, 大野木輝明, 喜多和彦: "準結晶を含む Al-V-Fe-M…", 粉体および粉末 治金 , 45(1998)817-823.

15) 武田義信: " アルミニウム粉末治金の展望 ", 軽金属 , 37 (1987)639-645.

16) A.Inoue, K.Ohtera, A.P.Tsai and T.Masumoto: "AluminumBased Amorphous Alloys with Tensile Strength ..", Jpn. J. Appl. Phys., 27(1988)L479-L482.

17) P.R.Bridenbaugh, W.S.Cebulak, F.R.Billman and G.H.Hildeman: "Particulate Metallurgy in Rapid Solidification", Light Metal Age, Oct., (1985)18-26.

18) K.N.Ramakrishnan, H.B.McShane and T.Sheppard: "The Influence of Powder Particle Size on the Mechanical Properties ...", Z. Metallkd, 85(1994)260-264.

19) K.Ohtera, A.Inoue and T.Masumoto: "High Mechanical Strength of Al-Y-Ni Amorphous Alloys by Warm...", Mater. Sci. Eng., A134(1991)1212-1214.

20) K. Ohtera, A.Inoue, T.Terabayashi, H.Nagahora and T.Masumoto: "Mechanical Properties of an $\mathrm{Al}_{88.5} \mathrm{Ni}_{8} \mathrm{Mm}_{3.5}$..", Mater. Trans., JIM, 33(1992)775-781.

21) H.Nagahama, K.Ohtera, K.Higashi, A.Inoue and T.Masumoto: "Mechanical Properties of Rapidly Solidified ...", Philos. Mag. Lett., 67(1993)225-230.

22) S.Adachi, T.Kubota, T.Kohno, M.Otsuki, M.Miyahara, J. Nagahora, K.Kita, T.Matsuda, M.Oguchi and A.Inoue: "Fatigue Strength Characteristics of Quasi-Crystal Aluminum ..", Aluminum Alloys (ICAA-6), ed T.Sato et al., 3(1988)1319-1324.

23) A.Inoue, T.Masumoto, T.Ekimoto, S.Furukawa, Y.Kuroda and H.S.Chen: "Preparation of Fe-, Co-, and '..", Metall. Trans. A, 19A(1988)235-242.

24) 木村久道, 井上明久, 笹森賢一郎, 河村能人, 大野木輝明, 喜多和彦: "Al-Cr-R $(R=C e, M m)$ 系合金 $P / M$ 材の機械的 性質 ", 粉体および粉末治金, 45(1998)738-743.

25）黒石農土, 明智清明: "アルミニウムの粉末冶金と複合材 料 ", 軽金属, 34(1984)537-546. 